\title{
現代の教会建築における \\ トップライトによる礼拝空間への採光手法の形態的特徴 \\ MORPHOLOGICAL CHARACTERISTICS OF ADOPTING DAY-LIGHT METHODS FROM SKYLIGHT IN WORSHIP SPACE OF CONTEMPORARY RELIGIOUS BUILDING
}

\author{
内藤誠人*1, 村田 涼 ${ }^{* 2}$, 安田幸一*3 \\ Tomohito NAITO, Ryo MURATA and Koichi YASUDA
}

\begin{abstract}
The aim of this study is to clarify the morphological characteristics of adopting day-light methods from skylights in the worship space of contemporary religious buildings built after 1950s. First, the morphological characteristics of worship space as seen from the relationships to chancel are analyzed by the planar and sectional form of worship space, planar composition of chancel and nave, arrangement of congregation's chairs. Second, the arrangements of skylights in worship space are analyzed by their section and plan. Finally, six major types of adopting methods of day-light from skylights are founded from twelve categorized types by their morphological characters.
\end{abstract}

\section{Keywords: Skylight, Daylighting, Worship Space, M orphology, Contemporary Architecture} トップライト, 自然採光, 礼扯空間, 形態, 現代建築

\section{1. 序}

\section{1. 研究の背景と目的}

自然光は，時間や季節によって変化することで空間の印象に大き く影響を与える要素の一つであり, 空間表現の手法として多くの建 築設計において重要な役割を担ってきた。特に，上方から採り入れ られる光は，パンテオンをはじめとする多くの建築空間を特徵付 けてきた採光形式であると言える，そのようなトップライト ${ }^{1)}$ は, 側空から容易に自然光を得られる外周部から離れた建物中央部に自 然光を採り入れることを可能とし，平面的に奥の深い空間を感じさ せることができる空であると言える。そして, 人工照明が登場する 以前には，ガラスや鉄骨をはじめとする建築技術の発達により，側 空に制約されていた平面計画がトップライトによる自然光利用によ って新たな形式を獲得した例もある. その後, 人工照明の登場によ って自然採光の必要性が薄れる時代があったものの, 近年は環境配 慮の必要性の高まりや光に対する価值観の変化などによって, トッ プライトによる自然光利用を行う建物は以前にも増して散見される ようになった。そして，トップライトからの採光には機能的に求め られる照度を確保するだけでなく, 多様な空間演出の手法を見出す ことができるのではないかと考える，筆者らはこれまでに，美術品 が壁面に展示されることから側空の設置が難しく, 自然採光を行う
場合にトップライトが主体となる美術館の展示室を対象に，均質な 展示空間が標榜される中で生まれた直方体の展示空間である「ホワ イトキューブ」を典型と仮定し，トップライトによる採光手法を展 示室の形態的特徵とトップライトの平面的配置との関係性から論じ てきた ${ }^{2)}$ 。これに続き本研究では，外部の景色に注がれる視線によ って礼拝への注意が妨げられてしまうことから側空が極力排除さ れ，トップライトによる上方からの採光が明るさを確保するためだ けでなく，神を象徴する天上の光としても重要な意味を担っている 礼拝空間を対象に, トップライトによる採光手法を形態的特徵から 考察するものである.

キリスト教教会の礼拝空間では，初期キリスト教教会以来，奥に 細長い左右対称や回転対称などの平面形式が繰り返し用いられ，上 部には切妻屋根やドーム屋根といった様々な屋根が架けられてい る。また，「司祭は朝日の方向に，祭壇に向かって朝の祈りを捧げ， 夕方にはバラ空から射込む夕陽を背に受けながら夕の祈りを捧げ

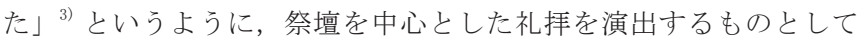
自然採光を捉えることができるが，祭壇を朝日の昇る東に向けると いうこのような規範的な方法は，様々な立地環境に置かれる現代の 礼拝空間では取り入れにくい状況にあると考えられる。そして現代 においては，建設技術の発展によってこれまで以上に多様な礼扯空

\footnotetext{
*1 関東学院大学建築 · 環境学部建築 · 環境学科 助手 · 修士 (工学)

*2 東京工業大学環境 · 社会理工学院建築学系 准教授 · 博士 (工学)

*3 東京工業大学環境 · 社会理工学院建築学系 教授・博士 (学術)
}

Assist., Dept. of Architecture and Environmental Design, Kanto Gakuin University, M.Eng.

Assoc. Prof., Dept. of Architecture, Tokyo Institute of Technology, Dr.Eng

Prof., Dept. of Architecture, Tokyo Institute of Technology, Ph.D. 
間を実現することが可能となり，さらにキリスト教カトリックの第 二バチカン公会議における現代改革にみられるように, 地域, 宗派 ごとにそれぞれの地域性を尊重しながら, 独自の祭祀儀礼に対応し た礼捀空間が認められたことで, 伝統的教会と比較して多様な礼捧 空間が実現されていると言える。そして，そのような礼扯空間にお いて，平面的に自由な位置に設けることが可能なトップライトによ る自然採光の方法にも様々なものがみられる. そこで本研究では, 現代におけるトップライトが配置された礼拝空間 ${ }^{4)}$ を対象に, 内 陣との関係からみた礼拝空間の平面形や断面形, トップライトの配 置などを検討し，トップライトによる礼帱空間への採光手法の形態 的な特徴の一端を明らかにすることを目的としている.

\section{2. 既往の研究及び本研究の意義}

建築における自然採光に着目した研究のうち, 本研究のように多 様な事例を広く収集選定し相対的に比較検討することで体系的に論 じた研究には, 室内における光の空間的特性を空の配置などの形態 的特徵から位置づけているもの ${ }^{5)}$, 視覚的に知覚可能な光の現象を 建築家の言説から捉え, 視覚心理学の知見から工学的に分析するも $の^{6)}$, 光の多義性を建築家による建築空間と光に関寸る言語描写か ら定量的に明らかにしているもの ${ }^{7)}$ がある。これらは, 実際の建築 空間や建築家の言説を手掛かりに，採光に関わる空間や空の形状， 配置といった要素に着目しており，本研究のように採光手法を形態 的に捉えることについての重要な視座を与えると考える. また，本 研究と同様に礼洋空間における自然採光に着目した研究には, 事例 を広く収集選定し相対的に比較検討することで体系的に論じたもの として, 礼拝空間の形態と開口部の配置の関係から採光手法の特徵 を論じた筆者らによるもの ${ }^{8)}$ のほか, 空間と開口部の形態分析に 加え礼拝空間の写真分析から光と陰影の表現手法を分析しているも の ${ }^{9)}$ があるが，いずれも空間に生じる光と闇の対比関係や陰影と いった現象を礼择空間における形態的特徵から論じており, トップ ライトによる採光手法を論じる本研究とは目的が異なる. また, 特 定の宗派に限定したものとして, 祭儀の差異がどのような室内環境 の差異として現れているのか, 複数の礼扯空間を実測調査し比較検 討した報告 ${ }^{10)}$ もあり，礼拝空間に求められる光環境の設計指針と して有益な知見を提供している。 さらに, 礼拝空間に配置された卜 ップライトに着目した研究としては, 自然光を主題にしながら設計 活動を展開したルイス・カーンによるファーストユニタリアン教会 のトップライトについて, 設計過程におけるトップライトの変遷か ら採光方法の変化とその意味について論じているもの ${ }^{11)}$ があるが, 特定の建築作品について詳細に調査・分析するものであり, 本研究 のように多くの事例を体系的に捉えるものとは異なった視点からの 知見を得ている. さらに, 現代の礼扯空間に関する研究には, 礼捧 空間に大きく影響を与える信徒の位置付けについて, 近現代におけ る変遷を論じたもの ${ }^{12)}$ があり, 現代の教会における課題として「聖 俗二元論」から聖職者と信徒を平等とする教会観への転換を指摘し ており, 礼拝空間のあり方が変容する要因の一つとして, 本研究に おいても有益な知見を提供している.

これら既往の研究に対し本研究は, 伝統的な教会建築と比較して 多様な展開がみられる現代の教会建築における礼拝空間を広く収集 し, 礼拝空間の形態とトップライトの配置との関係を比較検討寸る ことにより，トップライトによる自然採光の方法を形態的に論じる
ものであり, 現代の礼扯空間におけるトップライトを用いた採光手 法について有用な知見を与えるものとして意義がある.

\section{3. 研究の方法}

礼拝空間の形態と祭壇に対するトップライトの配置関係から， 卜 ップライトによる礼拝空間への採光手法の形態的特徴を明らかにす ることを目的としている，まず，宗教に関する価值観が大きく変化 したと言われる第二次世界大戦後の教会建築 ${ }^{13)}$ を対象に定め, そ の中からトップライトを有する礼拝空間を抽出し, 81 件の礼拝空 間が得られ ${ }^{14)}$, これらについて分析を行う。2 章では, 礼拝空間 の典型といえる長堂式及び集中式の平面形式を参照し，平面形を対 称性とプロポーションから検討する. 次に，礼拝空間を構成する領 域である内陣と身廊の位置関係について, 礼拝空間の中心 ${ }^{15)}$ に位 置する領域と内陣と身廊の位置関係及び身廊における会衆席の配列 を検討する. さらに, 礼择空間の断面形について, 祭壇に対する天 井の傾斜方向に着目し，祭壇が向く方向と祭壇と直交する方向の 2 方向から検討する。そして，これら平面形のプロポーションと断面 形の天井の傾斜方向の組み合わせから，礼扯空間の形態的特徵を明 らかにする．３章では，まず祭壇が向けられる方位を確認し．さら に，トップライトの断面配置を天井に対するトップライトの断面的 な位置と, 屋根及び天井に対する突出の有無から検討する。そし て, トップライトの平面配置を, 内陣と身廊の領域に対するトップ ライトの位置と, 礼择空間の周縁に対する位置から検討する. 4 章 では，前章までに検討した礼拝空間の形態パタンと，トップライト の配置パタンを重㸚わせて検討し，礼扯空間におけるトップライ トによる採光手法を導き, それらの形態的特徵の一端を明らかにす る (Figure1).

\section{2. 内陣との関係からみた礼拝空間の形態的特徵}

\section{1. 礼拝空間の平面形の対称性とプロポーション}

礼拝空間の平面形を対称性とプロポーションから検討した。対称 性については，対称軸をもつものを対称，刘称軸をもたないものを 非対称として分類した。 さらに，プロポーションについては，祭壇 の向きを基準とし，祭壇に対して奥行きのあるものを縱長，幅奥行 きとも等しいものを均等, 祭壇に対して奥行きが浅く左右に幅の広 いものを横長として分類した（Table1）．対称が大半を占めること から $(66 / 81)^{16)}$, 現代の礼扯空間においても平面形における対称性 は維持されていると言える. また, 平面形は, 縦長 (44/81) が最も 多く過半を占め, 次に均等 $(23 / 81)$, 横長 $(14 / 81)$ の順に該当数が みられた。

\section{2. 内陣と身廊の配置}

次に, 内陣と身廊の配置として礼扯空間の中心に位置する領域 と内陣と身廊の位置関係を整理し，領域同士が正対する対等な位 置関係にあるものを並置, 領域同士が包囲・被包囲のような主従 の位置関係にあるものを包囲として分類した（Table2）。まず，中 心に位置する領域は, 身廊 $(73 / 81)$ が大半であり, 位置関係は並置 (56/81) が過半数を占めた. さらに, 中心に位置する領域が身廊で 位置関係が並置の事例が最も多く該当事例がみられた $(43 / 81)$ 。ま た，中心に位置する領域が内陣で位置関係が並置は該当事例がみら れず，これは内陣が身廊に比べて面積的に大きくなるためであると 考えられる. 


\section{3. 身廊における会衆席の配列}

身廊における会衆席の配列について検討した. 会衆席の配列に は，全ての信徒が聖職者と正対するように会衆席が並ぶことで，祭 壇の重要性が強調されるもの，聖職者や信徒同士の視線が交差する ように会衆席が並ぶことで, 聖職者と信徒の一体性が強調されるよ うなもの，祭壇を挟んで信徒同士が向かい合うように会衆席が並ぶ ことで祭礼儀礼における信徒同士の出会いが強調されるようなもの がみられる。そして，これらの配列が内陣と身廊の配置と重叔合わ さることで，祭祀儀礼に関わる聖職者と信徒の多様な関係が成立し ていると考えられる. そこで, 信徒の視線が同じ方向を向くように 会衆席が並ぶものを平行, 信徒同士の視線が交わるように会衆席が 並ぶものを交差, 信徒同士が正対するように会衆席が並ぶものを対 面として分類した (Table3)。平行 (37/81) と交差（39/81）はほぼ同 程度の該当数があり, 対面 $(5 / 81)$ は少なかった。

\section{4. 天井傾斜からみた礼拝空間の断面形}

礼扯空間の断面形について祭壇が向く方向（以下，祭壇方向）と 祭壇に直交する方向（以下，直交方向）を設定し，この 2 方向にお ける天井傾斜によって断面形を分類した，まず，天井傾斜の有無に より断面形を平形と傾斜形に大別した。ささら，傾斜ありは頂部の 位置の違いにより，頂部が中央にあるものを山形，頂部が両端にあ るものを谷形，頂部が片端にあるものを坂形として分けた。また， 祭壇方向については, 坂形で頂部が前方にあるものを坂形 - 前, 後 方にあるものを坂形 - 後として区別した (Table4). 以上のように 分類した祭壇方向と直交方向の 2 断面を重叔合わせ，両断面ともに 平形のものを傾斜なし, 片方の断面のみ傾斜形のものを方向の違い により祭壇方向傾斜と直交方向傾斜, 両方向とも傾斜形のものを 両方向傾斜として 4 つの断面パタンに分類した. その結果, 傾斜 なし $(28 / 81)$ と両方向傾斜 $(27 / 81)$, 及び祭壇方向傾斜 $(14 / 81)$ と 直交方向傾斜 (12/81) はそれぞれ同数程度みられた。 また, 傾斜 を有する祭壇方向傾斜 (12/14), 直交方向傾斜 (8/12), 両方向傾斜 (16/27) では，それぞれ山形の組み合わせが最も多くみられた。

\section{5. 平面形と断面形からみた礼拝空間の形態}

プロポーションからみた平面形と傾斜方向からみた天井の断面

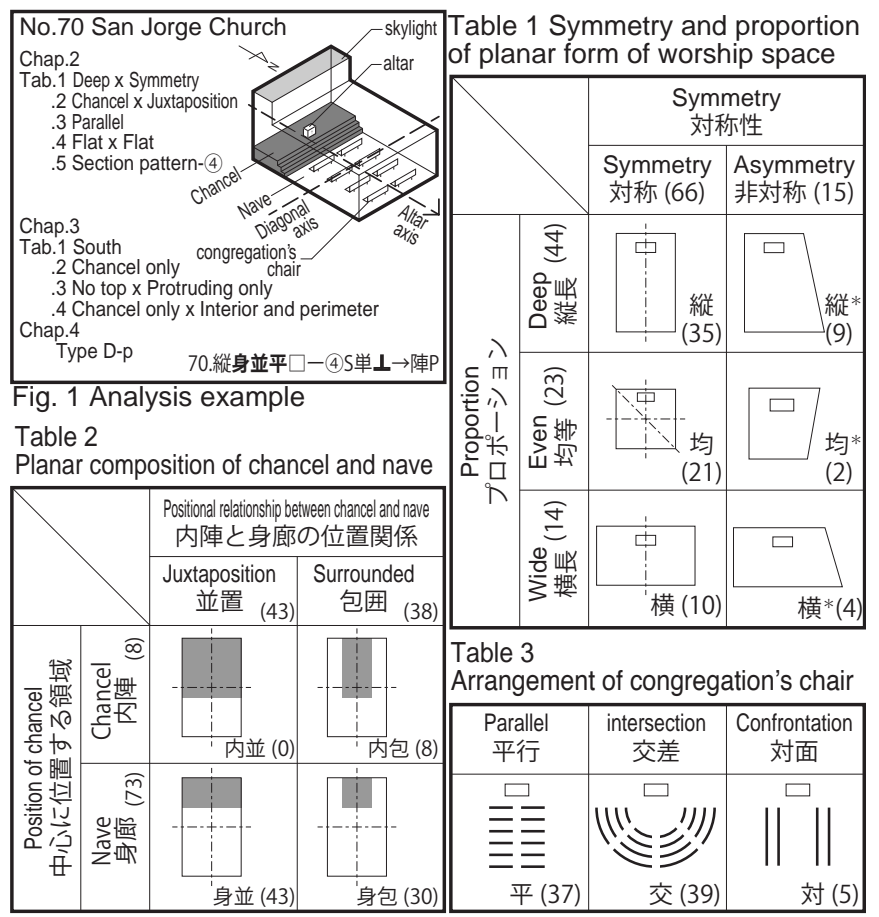

Table 4 Sectional form of the ceiling

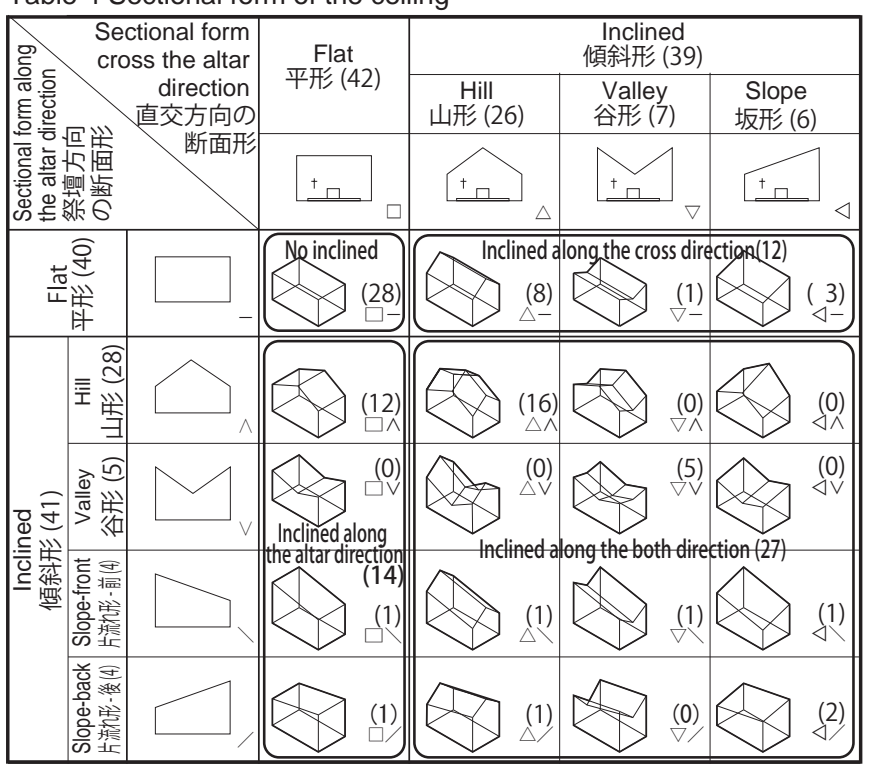

Table 5 Morphological characteristics of the worship space

\begin{tabular}{|c|c|c|c|c|c|}
\hline & \multirow{3}{*}{$\begin{array}{l}\text { No inclined } \\
\text { 傾斜なし }\end{array}$} & \multicolumn{2}{|c|}{$\begin{array}{c}\text { Sectional form of the ceiling } \\
\text { 天井の傾斜方向からみた断面パタン }\end{array}$} & (53) \\
\hline & & & Inclined along & one direction & $\begin{array}{c}\text { Inclined along the both direction } \\
\text { 両方向傾斜 }\end{array}$ \\
\hline & & & $\begin{array}{l}\text { Along the cross direction to altar } \\
\text { 直交方向傾斜 直 (12) }\end{array}$ & $\mid \begin{array}{c}\text { Along the parallel direction to altar } \\
\text { 祭壇方向傾斜 }\end{array}$ & 両方向傾斜 両 (27) \\
\hline \multirow{3}{*}{ 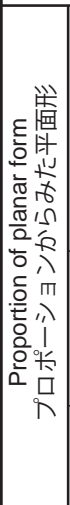 } &  & 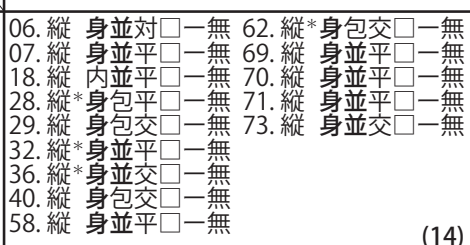 & 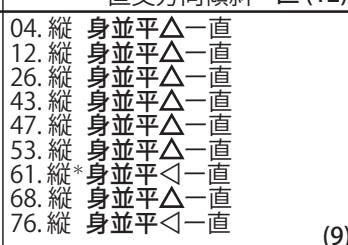 & 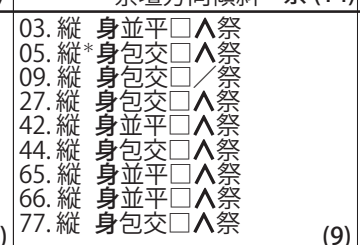 & 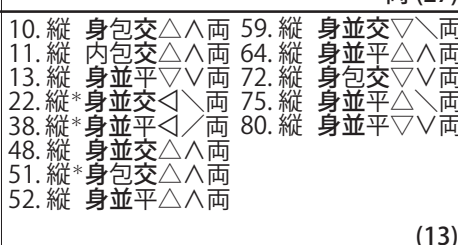 \\
\hline & 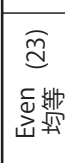 & 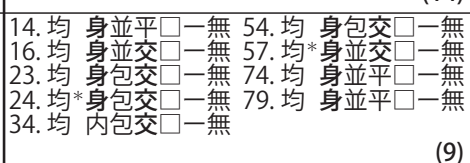 & $\begin{array}{l}\text { 67. 均 身並交 } \triangle \text { 一直 } \\
\text { 81. 均 身並平 } \triangle \text { 一直 }\end{array}$ & 56. 均 身並平 $\square \wedge$ 祭 & 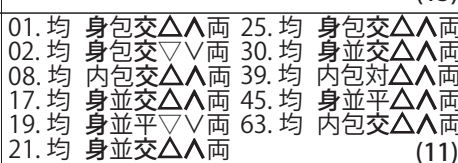 \\
\hline & 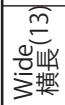 & 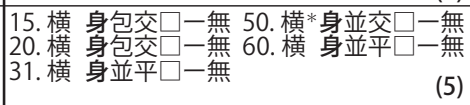 & 78. 横 内包対 $\nabla$ 一直 &  & 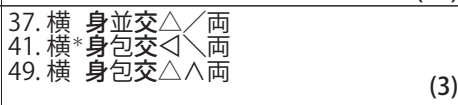 \\
\hline
\end{tabular}


形を重站合わせ，さらに内陣と身廊の配置と会衆席の配列を合わ せて検討し, 礼拝空間の形態的特徵を考察した（Tab1e5）. 全ての 断面形において縦長が最も多いが，傾斜なしでは縦長が半数であ り $(14 / 28)$, 次に均等が比較的多くあった $(9 / 28)$. 直交方向傾斜 は縦長が大半であり (9/12), 均等 $(2 / 12)$, 横長 (1/12) は僅かであ り，縦長に該当事例が特に偏るという傾向が伺える。祭壇方向傾斜 は縦長が過半であり $(9 / 14)$, 次に横長が多くあった $(4 / 14)$. 両方 向傾斜は縦長が約半数であり $(13 / 27)$, 次に均等が同程度に多くあ った $(11 / 27)$. 次に, 該当数の多くみられた縦長について断面パタ ンごとに内陣と身廊の配置と会衆席の配列をみると, 傾斜なしは配 置が並置のものが多く過半であり (10/14), 直交方向傾斜は配置が 並置で配列は平行が全てだった (9/9)。両方向傾斜は配置，配列と もに偏りがみられず，両方向傾斜は配置は並置が多く過半であり (9/13)，配列は際立った偏りはみられなかった。さらに，均等につ いて該当数の多くみられた傾斜なしと両方向傾斜をみると, 両者と もに配置には傾向がみられなかった一方で, 配列は交差が多く前者 (6/9)，後者（8/11）であるそれぞれ過半でああった。 以上より，天 井の傾斜方向と平面形のプロポーションの違いによって内陣と身廊 の配置や会衆席の配列との対応関係に異なる傾向を見出すことがで きる.

\section{3. 礼拝空間におけるトップライトの配置}

\section{1. 祭壇の方位}

礼拝空間の中で祭壇が配置される方位を検討し，四方位に分類し た (Table6). 東 $(32 / 81)$ が最も多くみられ, 礼拝空間の東側に祭壇 が設けられる事例が多いことがわかる，その一方で，北 (25/81)， 西 $(18 / 81)$ も該当数が比較的に多くみられ，東側に設けられること を基調としながらも多様な方位に祭壇が設けられていると言える.

\section{2. トップライトの断面配置}

トップライトの断面配置を，礼拝空間の天井におけるトップライ 卜の断面的な位置と屋根や天井に対寸る突出の有無からみたトップ ライトの断面形から検討した (Table7)。 天井におけるトップライ トの断面位置は, 天井を頂部の有無により傾斜天井と平天井に大別 し，傾斜天井のものはトップライトが頂部のみに配置されるものを 頂部のみ, 頂部と下部の両方に配置されているものを頂部あり, 頂 部以外に配置されているものを頂部以外に分類した. 次に, トッ プライトの断面形は，屋根上部への突出の有無及び天井下部への 突出の有無を検討し, 上下突出, 上突出, 下突出, 突出無しの 4 つに分類した．断面配置は，頂部なし $(28 / 81)$ と頂部あり $(27 / 81)$ が多く同程度ずつあり, 次に頂部のみ $(17 / 81)$ が多く, 頂部以外 (9/81) が最も少なかった. また, トップライトの断面形は, 突出 なし $(56 / 81)$ が最も多く過半あり, 次に上突出 $(21 / 81)$ が多く, 上 下突出 $(3 / 81)$ や下突出 $(1 / 81)$ は殆ど事例がみられなかった. さら に，断面配置と断面形を合わせて検討すると，頂部ありと頂部以外 は突出なしに事例の偏りがみられたが，頂部のみと頂部なしでは突 出なしと上突出の両方に事例の偏りがみられた。

\section{3. トップライトの平面配置}

トップライトの平面配置を, 内陣と身廊に対してトップライトが 位置する領域と, 礼拝空間の周縁に対する位置から検討した。まず, トップライトの個数について単数と複数にわけて捉え, 領域に対す
る配置をトップライトが内陣に配置されているものを内陣あり, 内 陣に配置されず身廊のみに配置されているものを身廊のみとして分 類した。 さらに, 内陣ありは内陣のみに配置されているものを内陣 のみ, 内陣と身廊の両方に配置されているものを内陣十身廊として

Table6 Orientation of altar

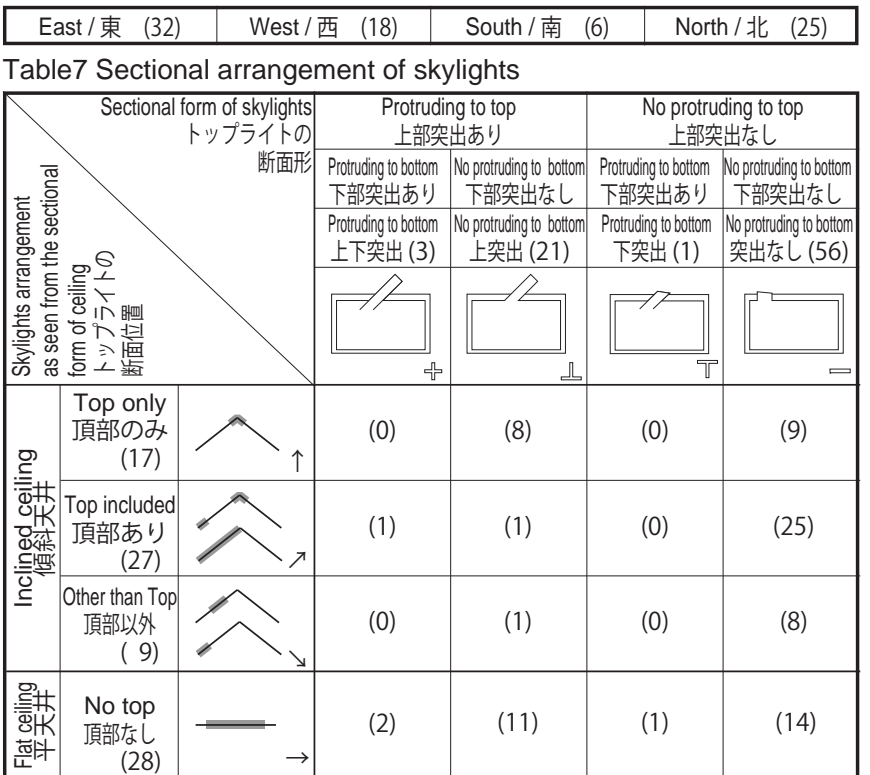

Table8 Planar arrangement of skylights

\begin{tabular}{|c|c|c|c|c|c|}
\hline & \multicolumn{3}{|c|}{$\begin{array}{c}\text { Skylights arrangement as seen from the relationship to the periphery } \\
\text { 周縁に対するトップライトの位置 }\end{array}$} \\
\hline & & & $\begin{array}{l}\text { Interior only } \\
\text { 中央のみ }\end{array}$ & $\begin{array}{l}\text { Interior and Periphery } \\
\text { 中央 }+ \text { 周緣 (30) }\end{array}$ & $\begin{array}{l}\text { Periphery only } \\
\text { 周縁のみ (28) }\end{array}$ \\
\hline \multirow{3}{*}{ 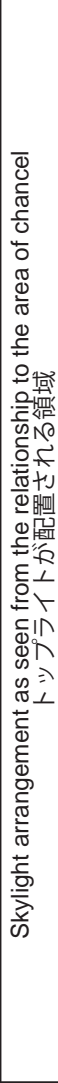 } & \multirow{2}{*}{ 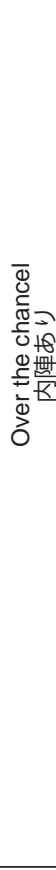 } & 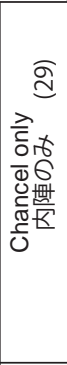 &  & 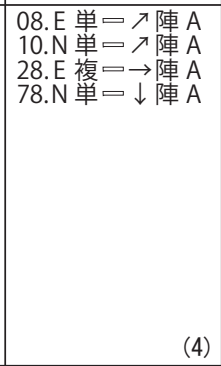 & 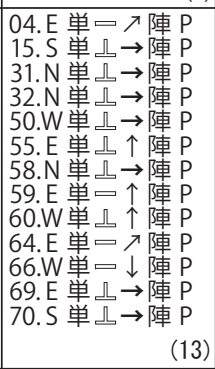 \\
\hline & &  & 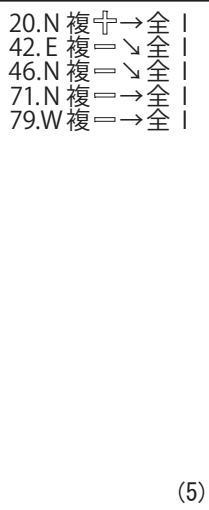 & 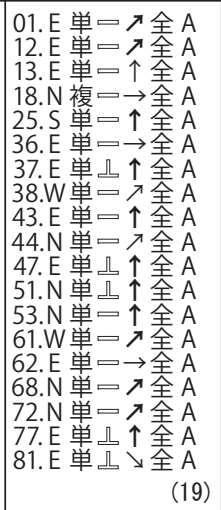 & 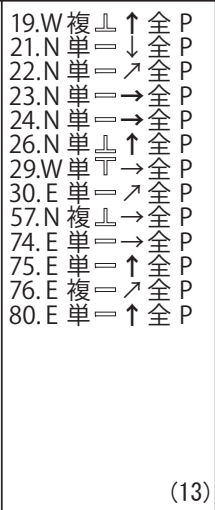 \\
\hline & & [n & 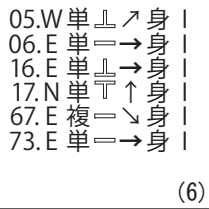 &  & 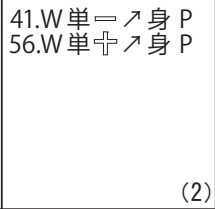 \\
\hline
\end{tabular}


分けた. また, 周縁に対するトップライトの位置は, 礼拝空間の周 縁から離れた位置に配置されるものを中央のみ, 中央から周縁に かけて配置されるものを中央十周縁, 周縁に沿って配置されるも のを周縁のみとして分類した (Table8). トップライトが配置され る領域では, 内陣十身廊が最も多く $(37 / 81)$, 次に内陣のみが多い (29/81)。つまり, 内陣に配置されることを基調として内陣だけで なく身廊にも配置される傾向が伺える. また, トップライトの位置 は, 中央十周縁 $(30 / 81)$, 周縁のみ $(28 / 81)$, 中央のみ (23/81) の 順に該当数がみられたことから, 中央と周縁の両方に配置されるこ とを基調として, 偏って配置される場合には中央よりも周縁に配置 されるという傾向が僅かに伺える.ささらに, 領域と位置を合わせて 検討するとそれぞれ該当数が多く得られた上位二項目が抽出でき, 内陣のみでは周縁のみ $(13 / 29)$ と中央のみ $(12 / 29)$ が多く同程度あ り, 内陣十身廊では中央十周緑 $(19 / 37)$ が約半数あり, 次に周緑の み $(13 / 37)$ が多くみられた。身廊のみでは中央十周縁 $(7 / 15)$ と中 央のみ $(6 / 15)$ が多く同程度あった。このことから, トップライト が内陣に配置されるものである内陣のみと内陣十身廊は共通してト ップライトの位置が周縁のみが多く, トップライトが身廊に配置さ れる内陣十身廊と身廊のみは共通して中央十周縁が多く, トップラ イトが配置される領域がどちらかに偏る内陣のみと身廊のみは共通 して中央のみが多いという傾向が伺える。つまり，トップライトの 位置が中央のみは片方の領域に偏って配置されるトップライトの位 置, 中央十周緑と周緑のみは内陣と身廊の両方に渡る配置を基調と して, それぞれ身廊と内陣に偏って配置されるトップライトの位置 であると言える。また, トップライトの断面配置をみると, 内陣の みでは頂部なし $(13 / 29)$, 身廊のみでは頂部あり $(8 / 15)$ が最も多く, トップライトが配置される領域が偏るものでは, 特定の断面配置に 偏る傾向が伺える. 一方で, 領域を横断するトップライトの平面配 置である内陣十身廊は頂部のみ $(12 / 37)$, 頂部なし $(11 / 47)$, 頂部 あり $(10 / 37)$ が同程度みられ, 多様なトップライトの断面配置がみ られた。

\section{4. トップライトによる礼拝空間への採光手法の形態的特徵}

前章までに得られた礼扯空間の断面形とトップライトの配置との 関係性を検討し，採光手法として $\mathrm{A} \sim \mathrm{L}$ の 12 種類の組み合わせを 得た（Table 9). まず，トップライトの配置パタンごとに採光手法 を捉えると, 内陣のみと内陣十身廊は, 複数の断面パタンとの対応 関係がみられる一方で, 身廊のみは特定の断面パタンのみと対応す る. そして, 断面パタンごとに捉えると, 傾斜なしと両方向傾斜は, 複数のトップライトの配置パタンに対応寸る断面パタンであり, 異 なる領域に対するトップライトの配置パタンに対応する汎用性のあ るものと言えるのに対し, 直交方向傾斜と祭壇方向傾斜はそれぞれ 特定の領域に対する配置パタンのみに対応する汎用性のない断面パ タンであると言える.

次に, 事例が集中した A, D, E, F, H, K の 6 つの主要な採光手法 について考察を行い, その形態的特徴を整理する. A, D はトップ ライトの配置が内陣のみの手法である.内陣上部に設けられたトッ プライトによる採光が内陣で完結し, 内陣と身廊が対比されるもの であると言える.A は断面パタンが傾斜なしの採光手法あり, トッ プライトの平面位置によって中央のみである A-i (5/14) と周縁のみ
である A-p (8/14) に事例数の偏りがみられた。A-iでは平面形のプ ロポーションが均等には事例がみられたが $(3 / 5)$, 横長には事例が みられなかった。 その一方で, A-p では横長には事例がみられ (4/9), 均等には事例がみられず, 両者の間で平面形のプロポーションに ついて異なる傾向が伺える。 また, A-i は内陣と身廊の配置には際 立った差異はみられないが, 会衆席の配列は平行が大半であった $(4 / 5)$ ． A-p は内陣と身廊の配置が身廊・並置 $(7 / 8)$, 配列が平行 (6/8) がそれぞれ大半であった。ささら A-pではトップライトの断 面形は上突出が全てであった $(8 / 8)$. D は断面パタンが両方向傾斜 の手法である. トップライトの平面位置が中央のみである D-i に事 例の偏りがみられた $(6 / 10)$. D-i は平面形は均等が過半であり $(4 / 6)$, 礼帱空間の中心に位置する領域が内陣 $(3 / 6)$ と身廊 $(3 / 6)$ が同数ず つあり，位置関係は包囲が全て (6/6), 配列は交差 (5/6) が大半で あった，以上より，トップライトの配置によって内陣が身廊から 対比されるものには, 断面形が傾斜なしである $A-i$ と $A-p$, 両方向 傾斜であるD-i があり, 前二者では共通して会衆席の配列は平行が 多く, 後者では交差が多いことから, 断面形の違いに対応して会 衆席の配列が異なるという傾向を捉えることができる．また，A-i とA-pではトップライトの平面位置の違いによって, 平面形のプロ ポーションが異なるという傾向を捉えることができる，E, F, H は トップライトの配置が内陣十身廊の手法で, トップライトの配置に より内陣と身廊が統合されるものであると言える。 Eは断面パタン が傾斜なしである. トップライトの位置による事例の偏りには際 立った傾向はみられなかったが，周縁のみである $\mathrm{E}-\mathrm{p}$ が最も多く 約半数あった $(5 / 11)$. E-p は平面形のプロポーションが均等 $(4 / 5)$, 内陣と身廊の配置は包囲 (4/5), 配列は交差 (4/5) がそれぞれ大半 であったＦは断面パタンが直交方向傾斜で唯一事例が多くみられ た手法である。トップライトの平面位置は中央十周縁である $\mathrm{F}-\mathrm{a}$ が 過半という事例数の偏りがみられた (5/9). F-a は平面形のプロポー ションは縱長 $(4 / 5)$, 内陣と身廊の配置は身廊・並置 $(4 / 5)$ がそれ ぞれ大半であり, 全て配列は平行であった $(5 / 5)$. H は断面パタンが 両方向傾斜である. トップライトの平面位置は中央十周縁である H-a (7/13) と周縁のみである H-p (6/13) がそれぞれ約半数ずつあり 事例数の偏りがみられた。 また, H-a は平面形のプロポーションは 縦長 (4/7), 交差 (5/7) がそれぞれ僅かに多く過半であり, 内陣と 身廊の配置には際立った偏りはみられなかった。 H-p は縦長 (3/6) と均等 $(3 / 6)$ がそれぞれ半数ずつ, 身廊・並置が過半であり $(4 / 6)$, 会衆席の配列には際立った偏りはみられなかった。両者を比較す ると, 相対的に $\mathrm{H}-\mathrm{a}$ では内陣と身廊の配置は包囲, 配列は交差が多 く, H-pでは内陣と身廊の配置は並置が多いといえる。また, トッ プライトの平面位置が中央のみは得られなかった。 以上より, トッ プライトの配置によって内陣と身廊が統合されるものには, 断面パ タンが傾斜なしである $\mathrm{E}-\mathrm{p}$, 直交方向傾斜である $\mathrm{F}-\mathrm{a}$, 両方向傾斜 である H-a と H-p があり, E-pでは内陣と身廊の配置は包囲, 会衆 席の配列は交差が多く, F-a ではそれぞれ並置, 平行が多いことか ら, 断面形の違いとトップライトの平面位置の違いによって内陣と 身廊の配置及び会衆席の配列が異なるという傾向を捉えることがで きる. また, H-a と H-p は直交方向及び祭壇方向の断面形, 内陣と 身廊の配置や会衆席の配列に偏りがみられず，際立った特徴を見出 せない多様なものであると言える.Kはトップライトの配置パタン 
が身廊のみの手法である. 断面パタンが祭壇方向傾斜で, それぞれ のパタンにおいて唯一得られた組合せのものである. トップライ トの平面位置は中央十周縁のものである $\mathrm{K}-\mathrm{a}$ のものが大半であり事 例に偏りがみられた $(5 / 7)$. K-a は平面形のプロポーションは縦長 のもの (3/5) と横長のもの (2/5) が約半数ずつ同程度に事例があり, 均等はみられなかった。また, 会衆席の配列は平行が比較的多く過 半であった $(3 / 5)$. 全ての事例が祭壇方向の断面形は山形であるこ とから，後方から前方に向かって上がる天井に設けられたトップラ イトが会衆席の後方から祭壇を照らすものであると考えられ, トッ プライトによる光が身廊から内陣を照らすことで両者が光によって 統合される手法であると言える. A やHではトップライトの平面位 置の違いにより，それぞれ異なる平面形のプロポーションや内陣と 身廊の配置及び会衆席の配列に対応する傾向を見出すことができる 一方で, D, E , F , K では特定のトップライトの平面位置に偏る傾 向が見出せる. さらに, 内陣と身廊の配置と会衆席の配列による礼 拝空間の平面構成の傾向に着目して採光手法を分類すると, それ ぞれ並置かつ平行という内陣と身廊が対応する採光手法として A-i, $A-p, F-a, H-p, K-a$ があり，包囲かつ交差に対応する採光手法と してD-i，E-p，H-a があり，それぞれに複数の採光手法を見出すこ とができ，このように現代の礼帱空間における採光手法の多様な展 開を捉えることができる.

以上より, トップライトが配置される領域と平面位置, 及び天井 の傾斜方向からみた断面形から検討し, それらの関係性を内陣と身 廊の配置や会衆席の配列の傾向と併せて捉えることで, 現代の礼拝 空間におけるトップライトによる採光手法の形態的特徴の一端を明 らかにした。

\section{5. 結}

本研究では, 現代の教会建築における礼拝空間を対象に，礼择空 間の形態的特徵を長堂式や集中式にみられる平面形における対称性 やプロポーションから礼择空間の平面形を捉え, さらに天井形状に よる断面形や内陣・身廊という領域に対するトップライトの配置と いった形態的な特徵を考察することで，礼拝空間におけるトップラ イトによる採光手法を検討した。

2 章では, 礼扯空間の形態を平面形及び断面形から検討した. 平 面形は，礼拝空間の典型といえる長堂式及び集中式の平面形式を参 照して対称性とプロポーションから捉え, 現代の礼拝空間において も対称性が維持されている傾向がみられた。 また, 断面形は祭壇が 向く方向と祭壇に直交する方向における天井傾斜から捉え，傾斜の ないもの，一方向のみ傾斜のあるもの， 2 方向とも傾斜のあるもの が同程度にみられ，天井傾斜の組み合わせにより多様な断面形が見 られることを明らかにした。

3 章では, 礼扯空間における自然採光を祭壇を中心とした礼拝を 演出する光として捉え, トップライトの平面配置を内陣 - 身廊とい う領域と周縁 - 中央という位置から検討し, トップライトの位置の 違いにより配置される領域が異なるという傾向を見出した.

4 章では, 前章までの結果をふまえ, 内陣・身廊という領域に対 するトップライトの配置と中央・周縁という平面位置, 及び天井の 傾斜方向からみた礼拝空間の断面形との関係性を検討し, 該当数の 多くみられた $6 つ の$ 主要な採光手法を得た。これらには, トップラ
イトが特定の平面位置に偏るものだけでなく, 複数の平面位置がみ られるものがあり, 後者では平面形のプロポーションや内陣と身廊 の配置及び会衆席の配列に異なる傾向を見出すことができる．さら に，傾斜のないものや両方向に傾斜するものは，内陣のみや内陣と 身廊の両方に渡るトップライトの配置と対応する汎用性のある断面 形である一方で，祭壇方向や祭壇に直交し一方向に天井が傾斜する ものは，それぞれ特定の領域に対するトップライトの配置に対応す る汎用性のない断面形であると言え，天井の傾斜方向からみた礼扯 空間の断面形とトップライトが配置される領域との関係性を明らか にした. さらに, 内陣と身廊の配置や会衆席の配列に対して, 複数 の採光手法を見出すことができ，現代の礼扯空間におけるトップラ イトによる採光手法の多様な展開を明らかにした。

以上，本研究では聖職者の領域である内陣と信徒の領域である身 廊という対比的な性格を有する領域によって構成される空間を対象 に，それら領域に対するトップライトの配置と天井の傾斜方向から みた礼扯空間の断面形との関係性により，トップライトによる採光 手法の形態的特徴を考察した。

また，礼拝空間を対象とした本稿と美術館の展示室を対象とした 既稿において得られた知見を比較すると，たとえば，切妻天井の棟 にトップライトが配置されるものや，周縁にトップライトが配置さ れるものなど, 美術品の鑑賞と礼捧という空間における異なる行為 に対して，共通する採光手法の形態的特徴を見出すことができるも のがある。このように，異なる建物用途に対して共通する形態的特 徵を有する採光手法が適応されることでトップライトを有する空間 の多様な展開を見出すことができる。ささらに, これらにみられる トップライトには，側空からの採光が届かない空間の奥への採光を 可能とするものだけでなく，空間の境界や壁面に採光するような周 縁に配置されるものも多くみられ，美術品や祭具が壁面に展示され る展示室や礼帱空間における特徵的な採光手法として捉えられる.

さらに, これまでに対象としてきた美術館の展示室や教会の礼拝 空間のような特定の用途を対象とする空間における採光手法と, ラ イフスタイルに応じた多様な機能がみられる住宅にける採光手法の 形態的な類似性を考察することも考えられる。あるいは，これまで 採光手法を内部空間における形態的特徵から考察してきたが，自然 採光の方法に大きく関わる緯度の違いによる地域性に着目し，地域 ごとにみられる採光手法の傾向や，共通する形態的特徽を有する内 部空間が地域差によってどのように外形として現れるのかといった 研究も考えられ, 今後の課題としたい 
Table 9 Adopting daylight methods by the combination of the sectional form of ceiling and lit area by skylights in the worship space

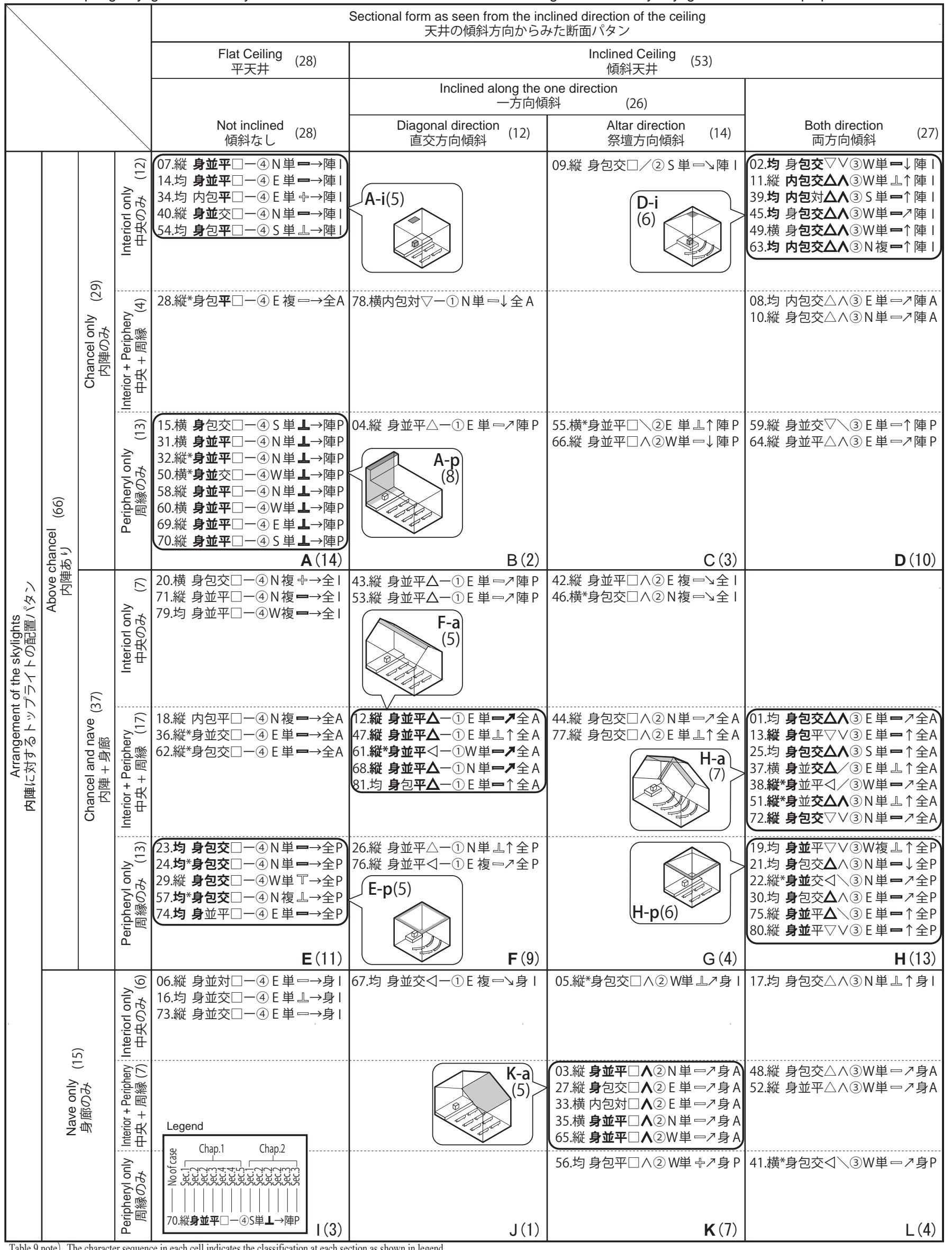

The numbers in () indicate the corresponding number. The number before () indicates the classification of type shown in Chapter 4. 
注 1）参考文献 1）の中で, 「トップライト」は上方からの採光. 特に屋根に あけられた天公を通じて自然光を採光することをいう。.また，「屋根に あけられた天空」とも記されており, 本研究では後者の屋根にあけら れた天空といら意を用いる。 また，参考文献 2) では，空を設置高さか ら, 天空, 頂側空, 側空, 高空, 底空, 掃き出し空に分類し, 天空に ついて『トップライト』や『スカイライト』とも呼ばれる.」として いるが, 本研究においては鋸屋根や越屋根といった頂側空も含めてト ップライトとしている. また, 建物の外周に設けられた高空は対象と していない.

注 2) 参考文献 3)

注 3) 参考文献 4)

注 4) 本研究では, 特定の宗派に限定せず信徒が集まって礼拝をささげる内 部空間を有する独立した教会建築を対象とし，ユダヤ教のシナゴーグ， キリスト教のカトリックに拉ける聖堂やプロテスタントにおける礼扯 堂や会堂, イスラム教のモスク, 学校や病院に付属寸る独立したチャ ペルを含めて対象とし，これらを『礼洋空間』と総称している.

注 5）参考文献 5)

注 6) 参考文献 6)

注 7) 参考文献 7)

注 8) 参考文献 8)

注 9）参考文献 9)

注 10）参考文献 10)

注 11）参考文献 11)

注 12）参考文献 12)

注 13) 本研究の資料対象の大半を占めるキリス卜教の中でも主要な宗派々 言えるカトリック教会について参考文献 4) では, 「20 世紀に入って まずは第 1 次世界大戦によって, 欧米主導の社会の矛盾が壊滅的な結 果を生み，そのプロセスでヨーロッパ社会内部に近代文明に対する根 本的な疑念が生まれた。第 2 次正解大戦を通じて人間性についての反 省, ヨーロッパ中心主義から地球社会への視点の拡大が行われ, 古い 価值観の崩壊を経験する過程のなかで, キリスト教の相対的矮小化が 認識されるようになった。このような状況の中で, キリス卜教も変化 する社会や価値観一の対応を迫られ，また一方宗教的な内容を確実な ものとする，あるいは刷新する動きも出てきたと思われる.」さらに， 「1945 年以来, カトリック教会もその自己認識において根本的な変化 を見せている。信仰内容の新しい方向づけ, 世界に対する認識, 新し い社会および世俗化の方向に対する認識などがその基底にある.」と 述べられており，その具体的な帰結として第 2 バチカン公会議 (1963) による現代改革が挙げられている。 つまり，2 度の世界大戦という世 界的に共通寸る経験が，キリスト教のカトリックにおいては第 2 バチ カン公会議として具体化されたと捉えることができ, カトリックのみ ならず無宗教の礼拝空間を資料対象とする本研究では, 宗教に関する 価值観が大きく変化したと言われる第二次世界大戦後の1945 年を事 例収集の条件とした。

注 14）本研究で対象とする礼扯空間の多くはキリスト教の聖堂や礼扯堂を中 心としており，ヨーロッパを始めアメリカや南米といった海外におい て多くの事例がみられる空間であると言える. 従って, 日本国内で出 版されている建築雑誌の中でも特に海外作品を主として掲載している 年間誌である「 $\mathrm{a}+\mathrm{u} 」$ 誌 (1971 年 1 月号から 2016 年 3 月号) と, 教会 建築の特集誌である「GA Contemporary Architecture 12-Religious」 を資料とし，第二次世界大戦の 1945 年以降に竣工した教会建築のうち, トップライトが配置されている礼拝空間を選定し, トップライトの位 置や形状, 祭壇の位置, 会衆席の配置など, 分析に十分な資料の得ら れた 81 作品を対象とした. そ内訳は, 大聖堂 (Cathedral)6 件, 教会 (Church) 44 件, チャペル (Chapel) 20 件, 修道院 (Monastery) 4 件, シ ナゴーグ (Synagogue) 3 件, 司教区センター (Parish Center) 4 件, 火 葬場 (Crematorium)1 件であった.

注 15) 本研究では, 祭壇を中心とした一体を「内陣」, 会衆席が配置されて いる一体を「身廊」とし, 現代の礼择空間では一般的に「内陣」と 「身廊」の境界は, 段差や床仕上げの切替えなどによって明示されて いることから，それらを手がかりに境界を抽出している.

注 16）礼扯空間の中心は, 対称な平面形については対称軸が 1 本のものは対 称軸の中点, 2 本以上のものはそれらの交点, 非対称な平面形につい ては外接する最小の長方形として求めている.

注 17) カッコ内の数字は, 分母は総数, 分子は該当事例数を表してる.
注 18）断面の切断位置によって異なる断面形が現われるものについては，傾 斜のある点に着目して分類している，また，異なる傾斜形が複合する ものは資料対象から得られず, 表においては省略している.

\section{参考文献}

1) K enchikudaijiten (Encyclopedia of A rchitecture and Building), Shokokusha, 2007 建築大辞典, 彰国社, 2007

2) Shadanhoujin Nihon Kenchiku Gakkai: Daylighting Design Guid, Gihodoushuppan, 2007

社団法人日本建築学会編：昼光照明デザインガイド，技報堂出版，2007

3) N aito, T., Suzuki, H., M urata, R. and Yasuda, K.: M orphorogical Characteristics of Daylighting $M$ ethods in Exhibition Rooms from Skylight in Contemporary A rt M useum, Journal of A rchitecture and Planning (Transaction of AIJ), N 0. 701, pp. 1553-1560, 2004. 7

内藤誠人, 鈴木春奈, 村田涼, 安田幸一：現代の美術館におけるトップ ライトによる展示室への採光手法の形態的特徴, 日本建築学会計画系論 文集，第 701 号，pp. 1553-1560，2014.7

4) Kenchikushichokenkyujo: Data File of A rchitectural Design \& Detail 36,

K youkaikenchiku, K enchikukenkyusha, 1992. 3

建築思潮研究所編：建築設計資料 36 教会建築，建築資料研究社，1992.3

5) K oizumi, T. and Suzuki, N .: Effects of the Sunlight on Spatial Orders and Their Causes in A rchitectural Spaces, Journal of A rchitecture, Planning and Engineering (Transaction of AlJ), N 0. 516, pp. 153-160, 1999. 2

小泉隆，鈴木信宏：建築空間における空間秩序的太陽光効果とそれらの 要因, 日本建築学会計画系論文集, 第 516 号, pp. 153-160, 1999.2

6) Yoshizawa, N., Horiguchi, H., Hirate, K. and Takeda, H.: The Classificationof Light by the Phenomenological $M$ ethod $-A$ study on the factors to produce the phenomenal light (Part1), J ournal of A rchitecture and Planning (Transaction of A J ), N o. 584, pp. 35-42, 2004. 10

吉澤望, 堀口裕美, 平手小太郎, 武田仁：現象学的見地からの光の分類 - フェノメナルな光の工学的条件に関する研究その 1 , 日本建築学会計画 系論文集，第 584 号，pp. 35-42，2004. 10

7) K itagawa, K., Naito, T. and Terada, K.: Polysemy of Light in Text Description of Buildings, J ournal of A rchitecture and Planning (Transaction of AlJ), N o. 680, pp. 2345-2355, 2012. 10

北川啓介, 内藤拓也, 寺田亨平：建築物の言語描写における光の多義性, 日本建築学会計画系論文集，第 680 号, pp. 2345-2355, 2012. 10

8) Takahashi, N., N aito, T., M urata, R. and Yasuda, K .: The Relationship of LightDarkness and Worship Spaces by Comparing the Forms of Plans and the Placement of Windows, Summaries of Technical Papers of A nnual M eeting, A rchitectural Institute of J apan, F-2, pp. 585-586, 2012. 9

高橋なつみ, 内藤誠人, 村田涼, 安田幸一：礼拝空間における形態と開 口部の配置からみた光と闇の対位法, 日本建築学会大会学術講演梗概集, F-2, pp. 585-586, 2012. 9

9) M iyamoto, T. and Shibata, A.: A Study of the Expression by Light and Shade in the Worship Spaces of Contemporary Churches, AlJ J ournal of Technology and Design, Kyushu, 54 , pp. 629-632, 2015. 3

宮本達弥, 柴田晃宏 : 現代教会建築の礼扯空間における光と陰影による 空間表現, 日本建築学会研究報告, 九州支部, 54, pp. 629-632, 2015.3

10) M urakami, A and Yumoto, N .: A M easurement on A coustic and Visual Environment to B uid Design-Indices for Contemporary Churches in Japan - $A$ Report on Filed M easurement of City - B uildings - Environment System, A IJ J ournal of Technology and Design 20, 44, pp. 247-250, 2014

村上晶子，湯本長伯：教会建築設計資料形成のための音・光環境に関す る実測報告：キリスト教会建築における都市一建築一環境システム概念の 研究, 日本建築学会技術報告集 20,44, pp. 247-250, 2014

11) Yanagita, T.and A sano, T.: On the First U nitarian Church's Skylight, A rchitectural Institute of J apan, Summaries of technical papers of annual meeting, F-2, pp. 407408, 1995. 7

柳田智弘, 浅野捷郎：ファーストユニタリアン教会のスカイライトにつ いて, 日本建築学会大会学術講演梗概集, F-2, pp. 407-408, 1995。7

12) Fukushima, A . and Doi, Y.: The Transition of the Definition and Recognition of "the Laity" in the Catholic Church in the M odern and Contemporary Periods and its Relation with Church Building A ctivities - Comparative studies on the history of the modern and contemporary church architecture 4, A rchitectural Institute of Japan, Summaries of technical papers of annual meeting, F-2, pp. 841-842, 2014. 9 
Appendix 1 Case Study List

\begin{tabular}{|c|c|c|c|c|c|c|c|c|c|c|c|}
\hline No. & Name & Year & C.*1 & T.*2 & Magazine & No. & Name & Year & c. & T. & Magazine \\
\hline 01 & Beth Cholom Synagogue & 1954 & $\mathrm{US}^{\prime 3}$ & $S^{* 4}$ & GACA*5 & 41 & Church at Lindenholzhausen & 1979 & $\mathrm{DE}$ & $\mathrm{C} 2$ & au198109 \\
\hline 02 & M.IT Kresge Chapel & 1955 & US & C3 & GACA & 42 & Immanuel Presbyterian Church & 1980 & US & $\mathrm{C} 2$ & au198109 \\
\hline 03 & Chapel of Helsinki University of Technoogy & 1957 & $\mathrm{FI}$ & C3 & GACA & 43 & Thorncrown Chapel & 1981 & US & C3 & au198106 \\
\hline 04 & Sanctuary for St. Paul's Lutheran Church & 1958 & US & C2 & au197306 & 44 & Garden Grove Community Church & 1981 & US & $\mathrm{C} 2$ & au198103 \\
\hline 05 & Vuoksenninska Church & 1959 & $\mathrm{Fl}$ & C2 & au198303 & 45 & Espirito Santo do Cerrado Church & 1982 & BR & $\mathrm{C} 2$ & au199902 \\
\hline 06 & Monastery of S ainte-Marie-de-la-Tourette & 1960 & FR & M & GACA & 46 & William R. Cannon Chapel & 1982 & US & C3 & au198305 \\
\hline 07 & The Atlantida Church & 1960 & |UY & C2 & au200308 & 47 & Rautavaara Church & 1982 & $\mathrm{FI}$ & $\mathrm{C} 2$ & au198310 \\
\hline 08 & Chapel of San Vincente de Paul & 1960 & $M X$ & C3 & GACA & 48 & Lieksa Church & 1982 & $\mathrm{FI}$ & $\mathrm{C} 2$ & au198501 \\
\hline 09 & St. J ohn's Abbey & 1961 & US & M & GACA & 49 & St. Matthew's Parish Church & 1983 & US & $\mathrm{C} 2$ & au198401 \\
\hline 10 & United Church of Rowaytown & 1962 & US & C2 & GACA & 50 & Myyrmaki Church and Parish Center & 1984 & $\mathrm{FI}$ & $\mathrm{C} 2$ & au199107 \\
\hline 11 & North Christian Church & 1963 & US & C2 & GACA & 51 & Affoltern Church & 1986 & $\mathrm{CH}$ & $\mathrm{C} 2$ & au198605 \\
\hline 12 & North Shore Congregation & 1964 & US & C3 & GACA & 52 & Church Complex at Ragnitz & 1987 & $A U$ & $\mathrm{C} 2$ & au199007 \\
\hline 13 & St. Mary's Cathedral & 1964 & J $\mathrm{P}$ & C1 & GACA & 53 & Mildred B. Cooper Memorial Chapel & 1988 & US & C3 & au199102 \\
\hline 14 & Tapiola Church & 1965 & $\mathrm{FI}$ & $\mathrm{C} 2$ & au200311ex & 54 & Chapel of Recconciliation & 1990 & $\mathrm{IR}$ & $\mathrm{C} 3$ & au199907 \\
\hline 15 & Church of Santa Ana & 1965 & ES & C2 & au197303 & 55 & Mannisto Church and Parish Center & 1992 & $\mathrm{FI}$ & $\mathrm{C} 2$ & au199504 \\
\hline 16 & Church of St. Peter & 1966 & SE & C2 & au200311ex & 56 & Cathedral in Evry & 1995 & FR & $\mathrm{C} 1$ & au199602 \\
\hline 17 & Tokyo Yamate Church & 1966 & J $\mathrm{P}$ & C2 & au198111 & 57 & The Chapel for St. Thomas University & 1997 & US & C3 & au199204 \\
\hline 18 & Chapel of the Holy Cross & 1967 & $\mathrm{FI}$ & C3 & au197307 & 58 & Leon Municipal Funerary Services & 2000 & ES & $\mathrm{C} 3$ & au200307 \\
\hline 19 & First Unitarian Church & 1969 & US & C2 & GACA & 59 & Our Lady of the Angels Cathedral & 2002 & US & $\mathrm{C} 1$ & GA72 \\
\hline 20 & Roman Catholic Church, Hague & 1969 & NL & C2 & GACA & 60 & Laajasalo Church & 2003 & $\mathrm{FI}$ & $\mathrm{C} 2$ & au200608 \\
\hline 21 & Temppeliaukio Church & 1969 & $\mathrm{Fl}$ & $\mathrm{C2}$ & au197307 & 61 & J ubilee Church & 2003 & IT & $\mathrm{C} 2$ & au200501 \\
\hline 22 & Interdenominational Chapel & 1969 & US & C3 & au197203 & 62 & Parish Centre St. Francis & 2004 & $\mathrm{DE}$ & $\mathrm{P}$ & au201112 \\
\hline 23 & Islev Church & 1970 & DA & C2 & au200311ex & 63 & Kärsämäki Church & 2004 & $\mathrm{FI}$ & $\mathrm{C} 2$ & au200608 \\
\hline 24 & Catholic Church in Oberentfelden & 1970 & $\mathrm{CH}$ & C2 & au197811 & 64 & St. Henry's Ecumenical Art Chapel & 2005 & $\mathrm{FI}$ & $\mathrm{C} 3$ & au200608 \\
\hline 25 & St. Mary's Cathedral & 1971 & US & $\mathrm{C} 1$ & au200311ex & 65 & Chapel of Quebrantoes & 2005 & PT & $\mathrm{C} 3$ & au200704 \\
\hline 26 & The Church of Saint Peter & 1971 & UY & C2 & au200308 & 66 & New Apostolic Church in Zuchwil & 2005 & $\mathrm{CH}$ & $\mathrm{C} 2$ & au200602 \\
\hline 27 & Papal Audience Hall & 1971 & VA & C3 & GACA & 67 & Firminy Church & 2006 & $\mathrm{FR}$ & $\mathrm{C} 2$ & au201003 \\
\hline 28 & Gug Church & 1972 & DA & C2 & au200311ex & 68 & New Monastery for Cistercian Nuns & 2006 & NO & M & au200712 \\
\hline 29 & Church Community Center & 1972 & $\mathrm{CH}$ & $\mathrm{C} 2$ & au198112 & 69 & Parish Center in Rivas-Vaciamadrid & 2008 & ES & $\mathrm{P}$ & au201112 \\
\hline 30 & St. Benedict's Abbey Church & 1973 & US & C2 & au197306 & 70 & San J orge Church & 2008 & ES & $\mathrm{C} 2$ & au201112 \\
\hline 31 & St. Francesso Church & 1974 & IT & $\mathrm{C} 2$ & au198403 & 71 & Crematorium Heimolen & 2008 & $\mathrm{BE}$ & $\mathrm{Cr}$ & au201004 \\
\hline 32 & The Church of St. Thomas & 1975 & $\mathrm{FI}$ & C2 & au199107 & 72 & Cathedral of Christ the Light & 2008 & US & $\mathrm{Cr}$ & au201502 \\
\hline 33 & Bagsvaerd Church & 1976 & DA & $\mathrm{C} 2$ & GACA & 73 & Foligno Parish Complex & 2009 & IT & $\mathrm{P}$ & au201112 \\
\hline 34 & Puchenau S piritual Welfare Center & 1976 & $A U$ & C3 & au197806 & 74 & Retreat Chapel & 2009 & $\mathrm{CL}$ & $\mathrm{C} 3$ & au201112 \\
\hline 35 & The Calvary Baptist Church & 1977 & US & $\mathrm{C} 2$ & au197810 & 75 & Kuokkala Church & 2010 & $\mathrm{FI}$ & $\mathrm{C} 2$ & au201107 \\
\hline 36 & Church, Bellikon & 1977 & $\mathrm{CH}$ & C2 & au198004 & 76 & Chapel of St. Lawrence & 2010 & $\mathrm{FI}$ & $\mathrm{C} 3$ & au201112 \\
\hline 37 & Cathedral of the Immaculate Conception & 1977 & US & C1 & au198106 & 77 & J J ewish Community Center of Mainz & 2010 & $\mathrm{DE}$ & $\mathrm{s}$ & au201112 \\
\hline 38 & Parish Center, Riopla & 1978 & IT & P & au197901 & 78 & Synagogue LIG & 2010 & NL & $\mathrm{s}$ & au201112 \\
\hline 39 & Our Lady's Priory & 1978 & US & M & au198205 & 79 & Martin Luther Church Hainburg & 2011 & AT & $\mathrm{C} 2$ & GACA \\
\hline 40 & Parish Church, Firhouse & 1979 & IR & C2 & au199907 & 80 & Kamppi Church & 2012 & $\mathrm{FI}$ & $\mathrm{C} 2$ & au201208 \\
\hline & & & & & & 81 & Nanjing Gangjin Garden Chapel & 2014 & $\mathrm{CN}$ & $\mathrm{C} 3$ & au201603 \\
\hline
\end{tabular}




\title{
MORPHOLOGICAL CHARACTERISTICS OF ADOPTING DAY-LIGHT METHODS \\ FROM SKYLIGHT IN WORSHIP SPACE OF CONTEMPORARY RELIGIOUS BUILDING
}

\author{
Tomohito NAITO ${ }^{* 1}$, Ryo MURATA ${ }^{* 2}$ and Koichi YASUDA ${ }^{* 3}$ \\ ${ }^{* 1}$ Assist., Dept. of Architecture and Environmental Design, Kanto Gakuin University, M.Eng. \\ ${ }^{* 2}$ Assoc. Prof., Dept. of Architecture, Tokyo Institute of Technology, Dr.Eng. \\ ${ }^{* 3}$ Prof., Dept. of Architecture, Tokyo Institute of Technology, Ph.D.
}

Introduction:

In the history of the worship space, such as basilica type and centralized temple type in Christian churches are characterlized as symmetry and rotational symmetry has been used as a norm of the worship space. And they also have symmetrical section along the axis or point, such as gable roof and dome, that have highest point above them. In addition, the altar will be directed to the east where the sun rises until recently as a norm. In this norm, the priest pray to the direction of the sun rising in the morning, and received the evening light in his back from rose window in the Gothic churches. So that it seems to be possible to understand the natural light to produce a worship by the priest and laities around the altar. In such worship space, skylights which can be arranged at free position is plan is considered to be attached position within the normative spatial types. This study aims to clarify the day lighting methods in the worship space of contemporary religious buildings by their morphological characteristics as seen from the relationships between the form of the worship space and the arrangement of the skylights towards the altar.

M ethods:

The worship spaces in the contemporary religious buildings built after 1950s were selected as cases to study. First, planar form of worship space were examined by its symmetry and proportion as refereing to the type of basillica and cetralized plan. In addition to this, the composition of chancel and nave, the arrangement of congregation's chair were also analyzed to know the direction created by theirarrangement. A nd sectional form of ceiling were analyzed by the axis along the altar and digonal axist of it.

Second, arrangement of skylight in plan was viewd. First, the orientation of altar was confirmed wether if they face to the east as its nome. Sectional form of skylights and planar arrangement of skylights were analyzed.

Third, based on all these results, we discussed the morphological characteristics of adopting day-light methods by the combination of sectional form of worship space as seen from the inclined direction of the ceiling and arrangement of skylights in worship space.

Results:

1) Symmetrical planar form at the worship space is still keeped as a nome. And deep proportion is the major in them. As the sectional form, flat ceiling and the ceiling inclined along the cross axis like dome are both major. The sectional shape can be characterized by the planar composition of chancel and altar, and the arrangement of congregation's chairs.

2)The major orientation of altar is still east in the four orientation even though the cases which don't face to east are more than half. Skylights which placed above chancel and nave are the major placement more than above chancel. By analayzed the combination between the area and the position toward to the periphery of whorship space, there are clear diferent relashinships between each sets.

3) The conclusion has came up with 6 adopting daylight methods by the combination of the sectional form of ceiling and lit area by skylights. There are some methods adopting to the original form of the worship space such as the basillica and centralized types. And some other methods to adopt new type of form of the worship spaces were founded, such as the sectional from inclined to the altar direction and the form with flat ceiling. A nd there are some methods which have different shape under the same types, especially by the placement of skylights. 